\title{
Mit tudunk az e-cigaretta káros hatásairól?
}

\author{
Nagy László Béla dr.
}

\begin{abstract}
Az elektronikus cigaretta világszerte egyre népszerúbb a dohányosok között. Ez új népegészségügyi dilemmát eredményezett. A vita központi témája az e-cigaretta okozta megbetegedési rizikó. Az általános vélekedés szerint az e-cigaretta nem valószínú, hogy olyan ártalmas, mint a hagyományos, de a relatív ártalom számszerüségéről kevés az adat. Sejtkultúrákban és állatokon végzett vizsgálatok azt mutatták, hogy az e-cigarettának is van többszörös negatív hatása. Humán akut egészségi hatásait illetôen kevés a tudományos evidencia. Humán tartós hatásai ismeretlenek, és nincs arra vonatkozó evidencia, hogy hosszabb távon biztonságosabb, mint a dohányzás. A jelen összefoglaló megvilágítja az e-cigarettának a tüdőre és a cardiovascularis rendszerre gyakorolt toxikus hatásairól nyert friss adatokat. Orv hetil. 2019; 160(45): 1767-1773.
\end{abstract}

Kulcsszavak: e-cigaretta, összetétel, in vitro vizsgálatok, állatkísérletek, humán megfigyelések

\section{What we know from the harmful effects of e-cigarettes?}

Electronic cigarettes are becoming increasingly popular with smokers worldwide. This has created an entirely new public health dilemma. The central issue in the debate is the disease risk imposed by e-cigarettes. It is generally acknowledged that e-cigarettes are unlikely to be as harmful as conventional cigarettes, but there are little data that quantify their relative harms. Experiments in cell cultures and animal studies show that e-cigarettes can have multiple negative effects. Scientific evidence regarding their human acute health effects is limited. The long term effects in humans are unknown, and there is no evidence that e-cigarettes are safer than tobacco in the long term. This review higlights the recent data regarding e-cigarettes toxicity impact on lung and cardiovascular system.

Keywords: e-cigarette, compounds, in vitro investigations, animal testings, human observations

Nagy LB. [What we know from the harmful effects of e-cigarettes?]. Orv Hetil. 2019; 160(45): 1767-1773.

(Beérkezett: 2019. június 27.; elfogadva: 2019. július 20.)

\section{Rövidítések}

$\mathrm{CAT}=(\mathrm{COPD}$ assessment test $) \mathrm{COPD}$-értékelési teszt; $\mathrm{CO}=$ szén-monoxid; COPD $==$ (chronic obstructive pulmonary disease) krónikus obstruktív tüdőbetegség; $\mathrm{CT}=$ (computed tomography) számítógépes tomográfia; DNS = dezoxiribonukleinsav; FDG-PET/CT = ${ }^{18}$ fluoro-dezoxi-glükóz-PET/CT; $\mathrm{FEF}=($ forced expiratory flow $)$ forszírozott kilégzési áramlás; $\mathrm{FeNO}=$ (fractional exhaled nitric oxide $)$ a kilégzett levegö $\mathrm{NO}$-tartalma; $\mathrm{FEV}_{1}=($ forced vital capacity in 1 second $)$ az elsó másodpercre eső erőltetett kilégzési térfogat; $\mathrm{FVC}=$ (forced vital capacity) erőltetett kilégzési vitálkapacitás; $\mathrm{MMF}=($ maximal midexpiratory flow) forszírozott középkilégzési áramlás; $\mathrm{MPO}=$ mieloperoxidáz enzim; NET = (neutrophil extracellular trap) neutrofil extracelluláris csapda; $\mathrm{NO}=$ (nitrogen monoxide) nitrogén-monoxid; PAFR = (platelet-activating factor receptor) a vérlemezke-aktiváló faktor receptora; $\mathrm{PET}=($ positron emission tomography) pozitronemissziós tomográfia; RR = relatív rizikó
A dohányzás számos népegészségügyi jelentőségű betegség kialakulásában szerepel. A dohányfüst több mint 7000 kémiai vegyületet tartalmaz, köztük több ezer toxikus komponenst. A vele kapcsolatos tüdőrák és COPD (krónikus obstruktív tüdőbetegség) a halálokok között előkelő helyen szerepel. Ugyanígy a cardiovascularis megbetegedések. Ezen megbetegedések és mortalitásuk nagymértékben csökkenthető volna a dohányzás abbahagyásával. Ennek fó akadálya a nikotin okozta addikció és a dohányzással kapcsolatos rituáléhoz való hozzászokás. A leszokást elősegítő módszereken kívül ezért kelt nagy figyelmet a hagyományos dohányzást helyettesítő elektronikus nikotinadagoló rendszerek megjelenése, köztük elsősorban az e-cigaretta (elektronikus cigaretta). Ennek koncepciója 1963-ra datálható, de az első készülék 2003-ban jelent meg, s a további technikai fejlődés során azóta terjedt el robbanásszerúen az egész világon. 
Ezzel kapcsolatban az egyik kérdés az, hogy a hagyományos dohányzás, cigaretta hozzászokását képes-e helyettesíteni, azaz elősegíteni az arról való leszokást. Erről azonban megjegyzendő, hogy sok dohányos párhuzamosan használja mindkettőt. $S$ ha az e-cigaretta nikotintartalmú, akkor ugyancsak addikciót okoz. Ezt a kérdést nem tárgyaljuk. A jelen irodalmi áttekintés arra próbál választ keresni, hogy a hagyományos dohányzáshoz viszonyítva milyenek az e-cigaretta káros hatásai. Az erre vonatkozó, egyre szaporodó közlemények egy része nem mentes a szubjektív megítéléstől, sem pró, sem kontra. Ennek legfőbb oka az, hogy még mindig túl kevés ismerettel rendelkezünk. Különösen igaz ez a hosszú távú humán hatásra, hiszen annak megítélésére minimum évtizedes követés szükséges. Főleg igaz ez a karcinogenitásra. A vizsgálatok túlnyomó része légzôszervi hatásra vonatkozik, lényegesen kevesebb a cardiovascularis vonatkozásra. A hatásmechanizmus kapcsán vannak adatok immunológiai hatásra. De szóba jöhet központi idegrendszeri befolyás, viselkedés, memóriakárosodás, tremor és izomspasmus, kontaktdermatitis, nausea, torokirritáció, szemirritáció.

Technikai adatok: a hagyományos cigarettához viszonyított legfóbb eltérés, hogy nincs benne dohány, nincs égés, és nincs füst. Az utóbbi helyett pára keletkezik. Az e-cigaretta részei: elem, fútőszál, porlasztókamra, folyadéktartály. A folyadék változó koncentrációjú oldott nikotin. Az oldószer propilén-glikol vagy glicerin és desztillált víz. Ehhez mesterséges ízesítők jönnek. A tartály újratölthető vagy cserélhető. A fütőszál vékony fémhuzal (nikkel, króm, ezüst vagy réz). Lehet a szerkezet nyomógombra induló, de automata is, melynél szenzor érzékeli a levegőáramlást és aktiválja a fütést. A fejlesztés generációi: az első generáció még külsejében a cigarettát utánozta, s zárt, nem utántölthető volt. A későbbiek utántölthetők. Lényeges, hogy a harmadik generáció feszültsége már nagyobb, 6-8 volt, a negyediké is ennyi, de változtatható (ezzel változik a nikotinerősség). Külsőleg sem hasonlítanak már cigarettára.

\section{A pára összetétele}

A legfontosabb káros anyagokat az 1. táblázat tartalmazza.

1. táblázat |A legfontosabb káros anyagok

\begin{tabular}{ll}
\hline Dohányfüst & E-cigaretta-pára \\
\hline Nikotin & Nikotin \\
Aromás szénhidrogének & Aromás szénhidrogének \\
Aldehidek & Aldehidek \\
Kadmium & Kadmium \\
Fenolok & \\
Nitrózaminok & \\
& Alkoholok \\
\hline
\end{tabular}

A dohányfüst és az e-cigaretta párája is sok ezer kémiai komponenst tartalmaz, de a különbségek jelentősek. Ez részben az alapanyag eltérő összetételével, részben azzal függ össze, hogy az e-cigaretta mintegy 540 fokon izzik, a hagyományosnak a hőmérséklete ennek csak 5-10\%-a. De az e-cigarettán belül is eltérések vannak a folyadékösszetétel, a hőmérséklet, a fütőáram, az egyes márkák között. A hagyományos füstje és az e-cigaretta párája közti különbségek részben eltérő kémiai komponenseket jelentenek. Van, ami az egyikben kimutatható, a másikban nem. Továbbá azonos kémiai vegyület eltérő koncentrációban van jelen. A vizsgálatokat különböző technológiával végzik. Meg lehet határozni a folyadék összetételét. Speciális „dohányzó géppel” állítják elő akár az e-cigaretta, akár a hagyományos égéstermékét. Ezt megfelelő eszközzel felfogják és elemzik. De meg lehet nézni a környező levegőbe jutó anyagokat is. Ennek során gondot jelent, hogy rengeteg márka van forgalomban, e-cigaretta és hagyományos is. Vagy típusosakat választanak ki, vagy a kereskedelemben leggyakrabban eladott fajtákat. Lehet átlagot is számolni. Tehát nincsenek hajszálpontos számok, melyek mindegyikre jellemzőek lennének. A dohányzó gép paramétereit állítani lehet és ezzel imitálni a különböző egyéni dohányzási módokat [1, 2]. A mérési eredmények értékelése is külön megfontolást igényel. Vannak anyagok, melyek munkahelyeken is előfordulnak, és léteznek hivatalos elöírások ezek megengedett határértékére (például US Occupation Safety and Health Administrations Permissible Exposure Limits). Mások egészségkárosító határértékei egyéb forrásból ismertek. A karcinogénekre nincs határérték, azok kívánatos koncentrációja 0.

Részecskeméret: a részecske koncentrációja, az átlagos méret és a méreteloszlás fontos meghatározója annak, hogy milyen mennyiségben jut a tüdőbe, és ott mennyire jut el a perifériáig. Különböző e-cigaretta-típusok és folyadék esetében a koncentráció és a részecskeméret kismértékben eltérő. A hagyományos cigarettánál ugyanez a helyzet, de az e-cigarettához képest nincs lényeges különbség $[3,4]$. Az e-cigaretta-aeroszolra a bimodális részecskedisztribúció a jellemző: nanopartikulumokból és szubmikron részecskékből áll. A nanorészecskéknek lehet különösen fokozott hatásuk. A környezeti részecskekoncentráció a hagyományosnál az e-cigarettáénak az 58-szorosa $[3,4]$. A kémiai összetétel azonban annyira eltérő, hogy nem ismert, hogy a méret és a koncentráció mennyiben befolyásolja a hatást. További kérdés, hogy ezen részecskék légutakba történő lerakódása milyen. Ugyanis ezt nemcsak a részecskeméret befolyásolja, hanem a koagulációjuk, higroszkópos tulajdonságuk, kémiai összetételük. Az e-cigaretta-részecskék higroszkóposabb volta növeli a légúti lerakódást.

Nikotintartalom: vannak nikotinmentes e-cigaretták is. A használók nagy része azonban a nikotinaddikció miatt élvezi. A folyadéktartály nikotinkoncentrációja különböző. Ezt gyárilag is megadják, bár sokszor eltérés van valós mérés esetén. A kérdés viszont az, hogy meny- 
nyi kerül a párába. Ezt természetesen számos technikai tényező befolyásolja. A folyadék koncentrációján kívül a fütési hőmérséklet, de a használó szívási technikája is. A nikotintartalmú e-cigaretta párájának és a hagyományos dohányfüstnek a nikotinkoncentráció-értékei átfedik egymást, szignifikánsan nem különböznek. Viszont a környezeti nikotinemisszió a dohányzásnál érthetően sokszorosan magasabb [5]. A másik kérdés a szervezetbe jutó mennyiség. A szérum-nikotintartalom is változó a márkától és a dohányostól függően. Az e-cigarettánál összehasonlítható nagyságrendű, mint a hagyományosnál $[6,7]$.

Telitetlen szénhidrogének: a diének közé tartozó izoprén fordul elő minimális mennyiségben. Nyálkahártyairritáns, és karcinogénként van nyilvántartva.

Aromás szénhidrogének: idetartozik többek között a naftalén, pirén, antracén, krizén, fenantrén, toluén. Ezek együttes koncentrációja a párában, illetve a dohányfüstben hasonló nagyságrendű [5]. A benzén- és toluéntartalom korrelál a nikotintartalommal. A benzén propilénglikolból és glicerinből is keletkezik, de benzolsavból és benzaldehidből is. Függ a fütési hőmérséklettől. Menynyisége a párában jóval kevesebb, mint a cigarettafüstben, de tartós e-cigarettázásnál nem közömbös. A toluén az e-cigarettában mintegy 120-szor kevesebb, mint a hagyományosban $[8,9]$. Ugyancsak sokkal kevesebb naftalént és pirént mértek az e-cigarettázók vizeletében. Az aromás szénhidrogének karcinogének. A benzén krónikus hatására leukaemiákat írtak le.

Alkobolok: az e-cigaretta-folyadék fó oldószere a víz mellett a glicerin és a propilén-glikol. Érthető módon az e-cigaretta-pára mindkettőt a hagyományos cigarettához képest sokszoros koncentrációban tartalmazza.

Fenolok: potenciálisan genotoxikus, kardiotoxikus és karcinogén hatásúak. A dohány több fenolvegyületet tartalmaz. Az e-cigaretta-folyadék nem tartalmaz kimutatható mennyiségben, hacsak nincs szennyeződés [10].

Oxovegyületek. Aldehidek: hő hatására keletkeznek a glicerinből és a propilén-glikolból. A reaktor hőmérsékletének emelkedésével koncentrációjuk exponenciálisan növekszik. De a hagyományos cigaretta füstjében is elöfordulnak, többek között cellulózból, pektinből, trigliceridekből keletkezve.

- Formaldehid: különböző e-cigaretta-márkák páráját megvizsgálva több szerző adatai szerint 150 puffban a munkahelyi határérték legfeljebb 3\%-a. Egy szál hagyományos cigaretta füstjében ennél magasabb a mennyisége [2]. A formaldehid krónikus expozíciója a légutak krónikus irritációját okozza a nyákmirigyek és serlegsejtek hyperplasiájával, a nyálkahártya mononukleáris sejtes infiltrációjával, a ciliumok elvesztésével és hámmetaplasiával. Egyes adatok szerint karcinogén is, bár ez humán vonatkozásban nem teljesen tisztázott.

- Acetaldehid: a különböző szerzők mérési eredményei nagy szórást mutatnak $[1,2,9]$. Mindenesetre az e- cigaretta-párában mért koncentrációnak a sokszorosa mérhető hagyományos cigarettafüstben [2].

- Dialdehidek: a glioxál és a metil-glioxál e-cigarettában kb. negyede a hagyományosénak [2].

- Telítetlen aldehidek: akrolein valamivel kevesebb van az e-cigaretta-párában. A hagyományosnál a biztonságossági határérték sokszorosa, de az e-cigaretta-párák egy részében is azt meghaladó értéket mértek [1, $2,9]$.

Ketonok. Aceton: koncentrációja a cigarettafüstben mintegy tíz-százszorosa a páráénak [1, 2].

Nitrogéntartalmú vegyületek. Aminok: nitrózaminok: Jelentős részük karcinogén. Az e-cigarettába szennyeződésként kerülhet, ugyanis a dohányból jut a nikotinba. Csaknem valamennyi e-cigaretta-folyadékban kimutatható. Igaz, a mennyisége minimális $[5,7,9]$. A hagyományos cigarettában a 40-380-szorosa [9]. A napi átlagos dohányzást figyelembe véve a napi expozíció e-cigarettánál $52 \mu \mathrm{g}$, hagyományosnál $93900 \mu \mathrm{g}$ [11]. Csakhogy állatkísérletben egereket tettek ki e-cigarettapára hatásának, és mérték közvetlenül a DNS-károsítást és a javító aktivitást tüdő-, szív- és húgyhólyagsejteken. A károsításon kívül kiderült, hogy mutagén nitrózamin ketonok keletkeznek in vivo a nikotin lebomlása során, s ezek nemcsak egér, de humán sejtkultúrában is mutagénnek bizonyultak [12].

Fémek: az aeroszol fémtartalmát mérve a konvencionálishoz képest az e-cigarettáé magasabb koncentrációban tartalmazott vasat, alumíniumot és nikkelt, azonos tartományban volt a réz, magnézium, ólom, króm és mangán, és kevesebb volt a cink, kadmium. A mérések alapján végzett számítások szerint extrém használat (8120 puff per nap) esetén a munkahelyi limitet a kadmium 10\%-kal meghaladja, a többi messze elmarad tőle [13]. A kadmium krónikus hatása vesekárosító és karcinogén.

Egyéb: kimutattak reaktív, rövid élettartamú, erősen oxidáló szabad gyököket is [14]. A szabad gyökök keletkezését az ízesítők is befolyásolják. Az aeroszolban nézve, 49 ízesítő közel fele volt ilyen hatású [15].

\section{In vitro vizsgálatok}

Citotoxicitás: az e-cigaretta-folyadék dózisfüggően citotoxikus a legkülönbözőbb sejtfajták tenyészetén in vitro (humán embrionális őssejtek, fibroblastok, monocyták, hörgóhámsejtek). A citotoxicitás független a nikotintartalomtól [16]. Az e-cigaretta-pára szintén a legkülönfélébb sejteken in vitro citotoxikus (keratinocyták, humán hörgő- és alveolaris hámsejtek, emlősfibroblastok, carcinomasejtek, humán endothelsejtek). Az egyes sejtféleségeken észlelt citotoxicitás eltérô volt ugyan, de abban egyeznek a vizsgálatok, hogy az e-cigaretta-pára citotoxicitása nagyságrendekkel kisebb, mint a hagyományos cigarettafüsté [17].

Az izesitók szerepe: az oldószerkomponensek szerepe a citotoxicitásban kisebb. A nikotin szerepe jelentős. Azo- 
nos nikotinkoncentráció mellett a citotoxicitás eltéró mértékében az ízesítók játszottak főszerepet. Számos ízesítő önmagában is citotoxikusnak bizonyult (diacetil, fahéjaldehid, acetoin, pentándion, o-vanillin, maltol, kumarin). A mentol-, kávé- és eperízesítésnél a pára in vitro citotoxicitása elérte a hagyományos cigarettafüst hatását $[16,17]$.

A citotoxicitás mechanizmusai: az e-cigaretta-pára dózisfüggően fokozta a reaktív oxigén gyökök termelését, és csökkentette az antioxidáns aktivitást. E hatások a nikotinmentes változatoknál is jelentkeztek, de nikotintartalom esetén kifejezettebbek voltak. Ugyanakkor az oxidatív stressz e-cigaretta-pára hatására lényegesen kisebb mértékű volt, mint dohányfüstre. Ugyanezt tapasztalták a proinflammatiós citokinek termelése, a génexpressziók befolyásolása és a DNS-károsító hatás vonatkozásában is [18].

Hatás a thrombocytákra: az e-cigaretta-pára fokozta az aktivációt, adhéziót, aggregációt - a nikotintartalmú kifejezettebben [19].

Hatás az endotheliumra: az e-cigaretta-pára az endothelsejteket károsítva aktiválja, megszakítja az endothel barrierfunkcióját, és a cytoskeleton átrendeződését okozza. Elsősorban a nikotintartalmú, de kisebb mértékben a nikotinmentes is [20].

\section{Állatkísérletek}

\section{A hatásmechanizmusra vonatkozóak}

Oxidatív stressz: az e-cigaretta-pára patkányokon és egereken egyaránt fokozta a szabad gyökök termelését, a proinflammatiós citokinek termelését, a DNS-károsodást, de kevésbé, mint a dohányfüst [21].

Karcinogén hatású enzimek aktiválása: patkánymodellen az e-cigaretta-pára fokozta a karcinogén aktiváló enzimek hatását, például a policiklusos aromás szénhidrogénekre hatókat [21].

Hatás a thrombocytákra: az e-cigaretta-pára fokozta a thrombocytaaggregációt és a thrombogenesist [22].

Egyéb hatások: egereket párával inhaláltatva akut hatásban több vizsgálat demonstrálta gyulladáskeltő hatását, megnőtt a hörgőmosó folyadék sejttartalma, főleg a macrophagok, a citokin- és proteázexpresszió, a nyáktermelés, a hiperreaktivitás [23]. Defektív lett a légutakban mind a bakteriális, mind a vírusinfekció elleni védelem [23]. Patkányokon vizsgálták a nikotinmentes pára akut, szubakut és krónikus hatását [24]. Az akut periódusban atelectasiákat, hörgőgyulladást, az alveolusok közti septumok ödémáját észlelték. Szubakutan a septummegvastagodás perzisztált, az atelectasiák csökkentek, de az alveolusok emphysemásan kitágultak, a hörgőgyulladás változatlanul fennállt. Krónikusan emphysema alakult ki a terminális és respiratoricus bronchiolusok és az alveolusok kitágulásával, az interalveolaris septumok megvékonyodásával.
Élettani hatás: egereken forszírozott oszcillációs technikával mérve a légzésfunkciót a dohányfüst hatására már 3 nap után nőtt a szöveti elaszticitás és a légúti ellenállás. 4 hét után ez ugyancsak a dohánnyal összefüggésben fokozódott. A metakolin-hiperreaktivitást is a hagyományos cigarettafüst fokozta. Mindezek pedig e-cigarettapára hatására kevésbé kifejezettek voltak [25].

\section{Humánvizsgálatok}

\section{Akut hatás}

Hatásmechanizmus: az e-cigaretta-szívás megemelte a plazma keringő mikropartikulum-szintjét, a különböző gyulladásos mediátorokét, a keringő endothel progenitorsejtek számát, megváltoztatta a bronchoszkópos bioptatumban az alveolaris macrophagok transzkriptomaprofilját [26]. A hagyományos cigarettához képest kevésbé okozott emelkedést a szérum oxidatívstressz-mutatóiban, valamint az orrnyálkahártyában a Pneumococcusok adhéziójában szerepet játszó PAFR (platelet-activating factor receptor) expressziójában.

Klinikum: egészséges nem dohányzókon az e-cigaretta akut hatásban panaszt nem okozott [26]. E-cigarettaexpozíció után csökkent átmenetileg a köhögésireflexérzékenység [27].

\section{Légzésfunkció}

Spirográfia: egészséges dohányosokon a hagyományos cigaretta akut hatásaként csökkent a $\mathrm{FEV}_{1}$, de a nikotinmentes e-cigaretta is azonos nagyságrendû romlást okozott [28].

Kishörgó-obstrukciós paraméterek: 'crossover' vizsgálatban dohányosok 3 napon át a hagyományosat, 3 napon át e-cigarettát szívtak. A hagyományos mellett szignifikánsan alacsonyabb volt a specifikus vezetőképesség és a $\mathrm{FEF}_{25}$, de nem volt különbség az intrathoracalis gázvolumenben [29].

\section{Egyéb légzésfunkciós vizsgálat}

Egészséges nem dohányzókon e-cigaretta akut hatásban nem befolyásolta a diffúziót, az oxigénszaturációt [26]. Ötperces e-cigaretta-használatra nőtt a kényszerrezgéses módszerrel mért teljes respiratorikus impedancia és rezisztencia 5 és $10 \mathrm{~Hz}$-nél egyaránt és a perifériás rezisztencia is. Lényegében ugyanezt észlelték asztmás és egészséges egyéneken, de az asztmásokon nagyobb mértékben [26]. Nikotinmentes e-cigarettát hagyományossal összehasonlítva a hagyományos szignifikánsan emelte a kilégzett levegő CO-tartalmát. A kilégzett levegő NOtartalma viszont nem változott egyiknél sem [28]. Akut hatásban (10 perc múlva) a nikotintartalmú e-cigaretta a légúti ellenállást növelte asztmás dohányosokon, egészséges dohányosokon és soha nem dohányzó egészsége- 
seken. A specifikus vezetőképességet csökkentette az egészséges soha nem dohányzókon; a nitrogénkilégzési görbe III. fázis meredekségét növelte asztmás dohányosokon, az oxigénszaturációt csökkentette egészséges dohányosokon és COPD-s dohányosokon. A szívfrekvenciát növelte valamennyi csoportban, kivéve a COPD-t. A nikotinmentes a légúti ellenállást növelte és a specifikus vezetőképességet csökkentette az egészséges soha nem dohányzókon [30]. Egyórás behatással vizsgálták a környezeti légzésfunkciós hatásokat egészségeseken és asztmásokon, és kényszerrezgéses módszerrel nem észleltek negatív hatást.

\section{Cardiovascularis hatás}

Összehasonlították echokardiográfiával a hagyományos és az e-cigaretta myocardiumfunkcióra gyakorolt akut befolyását. A hagyományos megnyújtotta a diasztolét, az e-cigaretta nem befolyásolta egyik paramétert sem [31]. Az e-cigaretta kevésbé emelte a szívfrekvenciát és a vérnyomást, mint a hagyományos [32]. Egészséges embereken növelte az endothel progenitorsejtek számát a vérben [33]. A placebóhoz képest az e-cigaretta terheléses vizsgálatban az elérhető csúcs-oxigénfogyasztást nem csökkentette [34]. Akut hatásban az e-cigaretta növelte az aortamerevséget és a szisztolés, valamint a diasztolés vérnyomást [35].

\section{Krónikus hatás}

\section{Légzöszervi}

Hatásmechanizmus: dohányosokat, e-cigaretta-használókat és egyáltalán nem dohányzókat hasonlítottak össze. Az indukált köpetben nézték a proteomikát, a mucin(MUC5AC és MUC5B) szintet, valamint a neutrofil extracelluláris csapdákat. A proteomika az egészségesektől eltért e-cigarettánál 81 , dohányzásnál 44 proteinben. A hámvédő proteinek (laktoferrin, lizozim) szintje dohányosokon magas volt, e-cigarettásokon nem. Az utóbbiaknál viszont több természetes immunfehérje szintje csökkentnek bizonyult. A neutrofilaktivációt jelző proteinek (neutrofilelasztáz, MPO, proteináz-3, azurocidin-1) dohányosoknál enyhén, e-cigarettánál jelentősen emelkedett. A vérből vett neutrofileket in vitro nézve a NET- (neutrofil extracelluláris csapda) képződés e-cigarettánál megnőtt. A teljes mucintartalom e-cigarettánál enyhén, dohányosokon jelentősen emelkedett. A MUC5AC mindkettőnél emelkedett, a MUC5A nem [36]. E-cigarettát, illetve hagyományos cigarettát használóktól nazális mintát véve a hámsejtek génexpresszióját megvizsgálva az immunszuppresszióval és gyulladással összefüggő génmintákat mutattak ki. Az érintett génekben különbség volt, de összességében az e-cigaretta nem mutatott kisebb hatást [37].

Egyéves követéssel nézték a hagyományosról e-cigarettára váltókon a breathomics-ot. A kiindulásihoz ké- pest a FeNO (a kilégzett levegő NO-tartalma) javult [38].

Klinikum: a vizsgálatok egy része egészséges embereken történt. Serdülőkön felmérték, hogy az előző év e-cigaretta-használata befolyásolta-e a légzőszervi tüneteket. A bronchitises tünetek rizikója majdnem kétszeresnek bizonyult (RR 1,85) a nem dohányzókéhoz képest. A rizikó korrelált a használat frekvenciájával [39]. Kérdőívvel 45128 tanulót felmérve az egyáltalán nem dohányzókhoz képest az e-cigaretta-használók rizikóhányadosa légzőszervi panaszokra 2,06, a hagyományos cigarettát alkalomszerüen használóké 1,72 [24]. Korábban nem dohányos e-cigaretta-szívókat 3,5 éven át követtek. A kontrollcsoportban soha nem dohányzók voltak. A panaszokban különbséget nem észleltek.

Az információk másik része betegek vizsgálatából adódott. A hagyományosról e-cigarettára áttérés csökkentette a COPD-exacerbatiók számát [40]. A CAT-pontszám javult [41]. Kétéves követéssel COPD-s betegeken szignifikánsan csökkent az exacerbatiós ráta (évi 2,3-ról 1,8-ra). Nem észlelték viszont a spirográfiás értékek javulását [42]. Orvos által diagnosztizált asztmáról 35904 egyetemistát kérdeztek meg. A jelenleg e-cigarettát használók között 3,9\%, a korábban használók között $2,2 \%$, a soha nem dohányzók között $1,7 \%$ volt a prevalencia. A nem dohányzókhoz viszonyítva a rizikóhányados e-cigarettánál 3,41, hagyományosnál 1,71, a jelenleg is dohányzókra vonatkozólag [43]. Kis esetszámú vizsgálatban nézték, hogy a hagyományosról e-cigarettára váltás hogyan befolyásolja asztmások állapotát. A spirográfiás paraméterek az egyéves követés során a kiindulásihoz képest javultak, a légúti hiperreaktivitás és az asztmakontrolláltság, de nem változott szignifikánsan az exacerbatiók száma [44]. Keresztmetszeti felmérésben 8087 résztvevőn hasonlították össze a dohányosok, az e-cigaretta-használók, a mindkettőt használók, az egyiket sem használók körében a légzőszervi megbetegedés prevalenciáját. A COPD- vagy asztmarizikó hányadosa e-cigarettánál az egyiket sem használókhoz képest: asztma e-cigarettánál 1,27, hagyományosnál 1,27. Krónikus pulmonalis betegségre e-cigaretta 2,58, hagyományos 2,98 [45]. Keresztmetszeti felmérésben 4432, különböző krónikus betegségben szenvedőnél mérték fel az e-cigaretta-használat, illetve a dohányzás prevalenciáját (magas vérnyomás, diabetes, cerebrovascularis megbetegedések, COPD, asztma, atopiás dermatitis, carcinoma, mentális zavar). Nem volt különbség [46].

Légzésfunkció: korábban nem dohányos e-cigarettaszívókat 3,5 éven át követtek. A kontrollcsoportban soha nem dohányzók voltak. Nem észleltek a spirográfiás paraméterekben, FeNO-ban negatív hatást. COPD-ben a hagyományosról e-cigarettára áttérés nem javította a légzésfunkciót. Javult azonban a 6 perces járásteszt [42]. COPD-s betegeken 3 éves követéssel megvizsgálták, hogy a dohányzást tovább folytatókhoz viszonyítva az e-cigarettára áttérók állapota hogyan változik. A 6 perces járásteszt javult, a FVC és $\mathrm{FEV}_{1}$-ben nem volt különbség 
[41]. Egyéves követéssel vizsgálták a hagyományosról e-cigarettára váltókon a légzésfunkciót. Javult a perifériás légutakat jellemző $\mathrm{FEF}_{25-75}$ [47]. Dohányos asztmásokon e-cigarettára áttérés után nőtt a $\mathrm{FEV}_{1}, \mathrm{FEF}_{25-75}$, csökkent a metakolin-hiperreaktivitás és az exacerbatiós ráta [44].

Cardiovasculáris hatás: összehasonlítva e-cigarettahasználókat nem dohányosokkal nagyobbnak bizonyult a szívfrekvencia-variabilitás, mely fokozott szimpatikus aktivitást jelez, és nem közömbös a cardiovascularis rizikó szempontjából [48]. Magas vérnyomásos dohányosokon e-cigarettára váltás után 12 hónapos követéssel mind a szisztolés, mind a diasztolés vérnyomás kisebb lett [40]. FDG-PET/CT szerint a nem dohányzókhoz viszonyítva e-cigaretta-használókon magasabb volt a lép és az aorta FDG-felvétele, de még magasabbnak bizonyult hagyományos cigarettát szívóknál [49]. Adatbázist feldolgozva a soha nem dohányzókhoz viszonyítva mindennapos e-cigaretta-használat esetén a szívinfarktus-rizikó hányadosa 2,25, mindennapos dohányzás esetén $2,95[50]$.

\section{Következtetések}

Az e-cigaretta-oldat és a pára nikotintartalma a gyártók, a készülék, a patron és a szívási szokás miatt nagyon változó, de mindenesetre kisebb, mint a hagyományos cigarettánál. Kb. a hagyományos csökkentett nikotintartalmúak tartományába esik. A környezeti szennyezés viszont - érthető módon - a hagyományos cigarettánál sokszorosan nagyobb. Az aromás szénhidrogének karcinogén voltára tekintettel az e-cigaretta sokkal kevésbé káros, mint a hagyományos. Még inkább érvényes ez a rákkeltő nitrózaminokra, melyek koncentrációja a cigarettafüstben sokszorosan nagyobb, mint az e-cigarettapárában. A propilén-glikol a hagyományosnál elhanyagolható, e-cigarettánál közelíti a veszélyes határt; a fenolokkal fordított a helyzet. Aldehidek, aceton: a hagyományosban jelentősen magasabb koncentrációjúak. A fémekkel a helyzet változó, egyes esetekben elérheti a veszélyességi határt.

In vitro vizsgálatokban és állatkísérletekben az e-cigaretta-pára kisebb oxidatív stresszt és kevesebb proinflammatiós citokin felszabadulását okozza. A genotoxicitásban részben más gének érintettek. Az endothelre és a thrombocytákra gyakorolt effektusokról nincsenek öszszehasonlító adatok. Állatkísérletben a légzésfunkciót a pára kisebb mértékben rontotta, mint a dohányfüst.

Emberen különböző légzésfunkciós módszerek eredményeit akut hatásban negatívan befolyásolta az e-cigaretta, de kevésbé, mint a hagyományos. Érthetően ezen negatív hatások légzési betegeken kifejezettebbek. Az észlelt cardiovascularis akut változások krónikus jelentősége nem ismert.

Jelenleg klinikai adataink elsősorban COPD-s vagy asztmás betegekről vannak. A nem dohányzókhoz képest az eredmények rosszabbak, de a hagyományosról az e-cigarettára áttérés javulást eredményez. Az asztmás panaszok csökkentek, a légzésfunkció javult. COPD-ben a panaszok csökkenésén kívül kevesebb lett az exacerbatio, és javult a terhelhetőség. A hosszú távú használat hatása nem ismert. Tüdőrák, COPD, cardiovascularis megbetegedés kialakulásához évtizedek kellenek. Az e-cigaretta bevezetése óta még nem telt el annyi idő, hogy meg lehetne vizsgálni, rizikótényező-e ezen kórképekre.

Anyagi támogatás: A közlemény megírása anyagi támogatásban nem részesült.

A szerző a cikk végleges változatát elolvasta és jóváhagyta.

Érdekeltségek: A szerzőnek a közlemény témáját illetően sem pénzügyi, sem személyes, sem egyéb érdekeltsége vagy ellenérdekeltsége nincs és nem is volt.

\section{Irodalom}

[1] Geiss O, Bianchi I, Barahona F, et al. Characterisation of mainstream and passive vapours emitted by selected electronic cigarettes. Int J Hyg Environ Health 2015; 218: 169-180.

[2] Margham J, McAdam K, Forster M, et al. Chemical composition of aerosol from an e-cigarette: a quantitative comparison with cigarette smoke. Chem Res Toxicol. 2016; 29: 1662-1678.

[3] Fuoco FC, Buionanno G, Stabile L, et al. Influential parameters on particle concentration and size distribution in the mainstream of e-cigarettes. Environ Poll. 2014; 184: 523-529.

[4] Fernández E, Ballbè M, Sureda X, et al. Particulate matter from electronic cigarettes and conventional cigarettes: a systematic review and observational study. Curr Environ Health Rep. 2015; 2: 423-429.

[5] McAuley TR, Hopke PK, Zhao J, et al. Comparison of the effects of e-cigarette vapor and cigarette smoke on indoor air quality. Inhal Toxicol. 2012; 24: 850-857.

[6] Etter JF, Bullen C. Saliva cotinine levels in users of electronic cigarettes. Eur Respir J. 2011; 38: 1219-1220.

[7] Flouris AD, Chorti MS, Poulianiti KP, et al. Acute impact of active and passive electronic cigarette smoking on serum cotinine and lung function. Inhal Toxicol. 2013; 25: 91-101.

[8] Moldoveanu S, Coleman W, Wilkins J. Determination of benzene and toluene in exhaled cigarette smoke. Beitr Tabakforsch Internat. 2008; 23:107-114.

[9] Goniewicz ML, Knysak J, Gawron M, et al. Levels of selected carcinogens and toxicants in vapour from electronic cigarettes. Tob Control 2014; 23:133-139.

[10] Long GA. Comparison of select analytes in exhaled aerosol from e-cigarettes with exhaled smoke from a conventional cigarette and exhaled breaths. Int J Environ Res Publ Health 2014; 11: 11177-11191.

[11] Farsalinos KE, Polosa R. Safety evaluation and risk assessment of electronic cigarettes as tobacco cigarette substitutes: a systematic review. Ther Adv Druf Safe 2014; 5: 67-86.

[12] Lee HW, Park SH, Weng M, et al. E-cigarette smoke damages DNA and reduces repair activity in mouse lung, heart, and bladder as well as in human lung and bladder cells. Proc Natl Acad Sci U S A 2018; 115: E1560-E1569.

[13] Olmedo P, Goessler W, Tanda S, et al. Metal concentrations in e-cigarette liquid and aerosol samples: the contribution of metallic coils. Environ Health Perspect. 2018; 126: 027010. 
[14] Goel R, Durand E, Trushin N, et al. Highly reactive free radicals in electronic cigarette aerosols. Chem Res Toxicol. 2015; 28: $1675-1677$.

[15] Bitzer ZT, Goel R, Reilly SM, et al. Effect of flavoring chemicals on free radical formation in electronic cigarette aerosols. Free Radic Biol Med. 2018; 120: 72-79.

[16] Muthumalage T, Prinz M, Ansah KO, et al. Inflammatory and oxidative responses induced by exposure to commonly used e-cigarette flavoring chemicals and flavored e-liquids without nicotine. Front Physiol. 2018; 8: 1130.

[17] Cervellati F, Muresan XM, Sticozzi C, et al. Comparative effects between electronic and cigarette smoke in human keratinocytes and epithelial lung cells. Toxicol in Vitro 2014; 28: 999-1005.

[18] Romagna G, Allifranhini E, Bocchietto E, et al. Cytotoxicity evaluation of electronic cigarette vapor extract on cultured mam malian fibroblasts (ClearStream-LIFE): comparison with tobacco cigarette smoke extract. Inhal Toxicol. 2013; 25: 354-361.

[19] Hom S, Chen L, Wang T, et al. Platelet activation, adhesion, in flammation, and aggregation potential are altered in the presence of electronic cigarette extracts of variable nicotine concentrations. Platelets 2016; 27: 694-702.

[20] Schweitzer KS, Chen SX, Law S, et al. Endothelial disruptive proinflammatory effects of nicotine and e-cigarette vapor exposures. Am J Physiol Lung Cell Mol Physiol. 2015; 309: L175L187.

[21] Canistro D, Vivarelli F, Cirillo S, et al. E-cigarettes induce toxicological effects that can raise the cancer risk. Sci Rep. 2017; 7: 2028.

[22] Qasim H, Karim ZA, Silva-Espinoza JC, et al. Short term e-cigarette exposure increases the risk of thrombogenesis and enhances platelet function in mice. J Am Heart Assoc. 2018; 7: e009264.

[23] Hwang JH, Lyes M, Sladewski K, et al. Electronic cigarette inhalation alters innate immunity and airway cytokines while increasing the virulence of colonizing bacteria. J Mol Med. 2016; 94 667-679

[24] Pikaljuk VS, Salanin VV, Zsuravel EA, et al. Structural changes in the lung of rats as the result of the aerosol inhalation of nonnicotine liquid used for electronic cigarettes. Zs Anat Histopat. 2016; 5: 41-45. Available from: https://anatomy.elpub.ru/ jour/article/view/283/283 [accessed: September 26, 2019]. [Russian]

[25] Glynos C, Bibli SI, Katsaounou P, et al. Comparison of the effects of e-cigarette vapor with cigarette smoke on lung function and inflammation in mice. Am J Physiol Lung Cell Mol Physiol. 2018; 315: L662-L672.

[26] Staudt MR, Salit J, Kaner RJ, et al. Altered lung biology of healthy never smokers following acute inhalation of e-cigarettes. Respir Res. 2018; 19: 78.

[27] Dicpinigaitis PV, Lee CA, Dicpinigaitis AJ, et al. Effect of e-cigarette use on cough reflex sensitivity. Chest 2016; 149: 161-165.

[28] Ferrari M, Zanasi A, Nardi B, et al. Short-term effects of a nicotine-free e-cigarette compared to a traditional cigarette in smokers and non-smokers. BMC Pulm Med. 2015; 15: 120.

[29] Unverdorben M, Mostert A, Munjal S, et al. Acute effects of cigarette smoking on pulmonary function. Regul Toxicol Pharmacol. 2010; 57: 241-246.

[30] Palamidas A, Tsikrika S, Katsaounou PA, et al. Acute effects of short term use of e-cigarettes on airways physiology and respiratory symptoms in smokers with and without airways obstructive diseases and in healthy non smokers. Tob Prev Cessation 2017; 3: 5 .

[31] Farsalinos KE, Tsiapras D, Kyrzopoulos S, et al. Acute effects of using an electronic nicotine-delivery device (electronic cigarette) on myocardial function: comparison with the effects of regular cigarettes. BMC Cardiovasc Disord. 2014; 14: 78.
[32] Yan XS, D'Ruiz C. Effects of using electronic cigarettes on nicotine delivery and cardiovascular function in comparison with regular cigarettes. Regul Toxicol Pharmacol. 2015; 71: 24-34.

[33] Antoniewicz L, Bosson JA, Kuhl J, et al. Electronic cigarettes increase endothelial progenitor cells in the blood of healthy volunteers. Atherosclerosis 2016; 255: 179-185.

[34] Fogt DL, Levi MA, Rickards CA, et al. Effects of acute vaporized nicotine in non-tobacco users at rest and during exercise. Intern J Exerc Sci. 2016; 9: 607-615

[35] Vlachopoulos C, Ioakeimidis N, Abdelrasoul M, et al. Electronic cigarette smoking increases aortic stiffness and blood pressure in young smokers. J Am Coll Cardiol. 2016; 67: 2802-2803.

[36] Reidel B, Radicioni G, Clapp PW, et al. E-cigarette use causes a unique innate immune response in the lung, involving increased neutrophilic activation and altered mucin secretion. Am J Respir Crit Care Med. 2018; 197: 492-501.

[37] Martin EM, Clapp PW, Rebuli ME, et al. E-cigarette use results in supression of immune and inflammatory-response genes in nasal epithelial cells similar to cigarette smoke. Am J Lung Cell Mol Physiol. 2016; 311: L135-Ll44.

[38] Campagna D, Cibella F, Caponneto P, et al. Changes in breathomics from a 1-year randomized smoking cessation trial of electronic cigarettes. Eur J Clin Invest. 2016; 46: 698-706.

[39] McConnell R, Barrington-Trimis JL, Wang K, et al. Electronic cigarette use and respiratory symptoms in adolescents. Am J Respir Crit Care Med. 2017; 195: 1043-1049.

[40] Polosa R, Morjaria JB, Caponnetto P, et al. Blood pressure control in smokers with arterial hypertension who switched to electronic cigarettes. Int J Environ Res Publ Health 2016; 13: 1123.

[41] Polosa R, Morjaria JB, Prosperini U, et al. Health effects in COPD smokers who switch to electronic cigarettes. A retrospective-prospective 3-year follow-up. Int J Chron Obstruct Pulmon Dis. 2018 ; 13: 2533-2542.

[42] Polosa R, Morjaria JB, Caponnetto P, et al. Evidence for harm reduction in COPD smokers who switch to electronic cigarettes. Respir Res. 2016; 17: 166.

[43] Cho JH, Paik SY. Association between electronic cigarette use and asthma among high school students in South Korea. PLoS ONE 2016; 11: e015022.

[44] Polosa R, Morjaria J, Caponnetto P, et al. Effect of smoking abstinence and reduction in asthmatic smokers switching to electronic cigarettes: evidence for harm reversal. Int J Environ Res Publ Health 2014; 11: 4965-4977.

[45] Wills TA, Pagano I, Williams RJ, et al. E-cigarette use and respiratory disorder in an adult sample. Drug Alcohol Depend. 2019; 194: 363-370.

[46] Kioi Y, Tabuchi T. Electronic, heat-not-burn, and combustible cigarette use among chronic disease patients in Japan: a crosssectional study. Tob Induc Dis. 2018; 16: 41.

[47] Cibella F, Campagna D, Caponnetto P, et al. Lung function and respiratory symptoms in a randomized smoking cessation trial of electronic cigarettes. Clin Sci. 2016; 130: 1929-1937.

[48] Moheimani RS, Bhetraratana M, Yin F. Increased cardiac sympathetic activity and oxidative stress in habitual electronic cigarette users. Implications for cardiovascular risk. JAMA Cardiol. 2017; 2: $278-284$.

[49] Boas Z, Gupta P, Moheimani RS, et al. Activation of the "splenocardiac axis" by electronic and tobacco cigarettes in otherwise healthy young adults. Physiol Rep. 2017; 5: el3393.

[50] Bhatta DN, Glantz SA. Electronic cigarette use and myocardial infarction among adults in the US Population Assessment of Tobacco and Health. J Am Heart Assoc. 2019; 8: e012317.

(Nagy László Béla dr. Felsödobsza, Thököly u. 1., 3847 e-mail: nagylb@borsodweb.eu) 